\section{Single and Sequential Colorant Application Effects on Buffalograss and Zoysiagrass Color during Dormancy}

\author{
Ross C. Braun ${ }^{1,3}$, Jack D. Fry ${ }^{1}$, Megan M. Kennelly², \\ Dale J. Bremer ${ }^{1}$, and Jason J. Griffin ${ }^{1}$
}

ADDITIONAL INDEX WORDs. japanese lawngrass, warm-season turfgrasses, winter color

SUMmARY. In the transitional climates, warm-season turfgrasses are more heat and drought resistant and require fewer pesticide and fertilizer inputs than cool-season turfgrasses, but an extended winter dormancy period in warm-season turfgrasses makes them less attractive. Our objective was to evaluate color intensity and persistence of colorants applied at two volumes, once or sequentially, on buffalograss (Buchloe dactyloides) maintained at 2.5 inches and zoysiagrass (Zoysia japonica) maintained at 0.5 inch. Field studies were conducted in Manhattan, KS, and Haysville, KS, from Oct. 2013 to May 2014 on dormant 'Sharpshooter' and 'Cody' buffalograss and 'Meyer' zoysiagrass. The colorants Green Lawnger, Endurant, and Wintergreen Plus were applied at 100 or $160 \mathrm{gal} / \mathrm{acre}$ in autumn (single application) or autumn plus midwinter (sequential application). Every 2 weeks, visual turf color was rated on a 1 to 9 scale $(9=$ best $)$ with ratings based on the intensity of the color, not the color (hue) of green. Few differences in color persistence occurred among colorants, but color persisted longer at the higher spray volume. In general, buffalograss receiving a single autumn colorant application had acceptable color (i.e., a visual rating $\geq 6$ ) for 55-70 days at $100 \mathrm{gal} / \mathrm{acre}$ or 5588 days at $160 \mathrm{gal} / \mathrm{acre}$. Zoysiagrass receiving a single autumn colorant application had acceptable color for 56-97 days at $100 \mathrm{gal} / \mathrm{acre}$ or 97-101 days at $160 \mathrm{gal} / \mathrm{acre}$. Across all sites, a sequential midwinter application applied at $160 \mathrm{gal} / \mathrm{acre}$ on buffalograss and both application volumes on zoysiagrass provided acceptable green turf color from that point until spring green-up. Most buffalograss plots receiving the sequential midwinter application at $100 \mathrm{gal} / \mathrm{acre}$ had acceptable color from that point until spring green-up. Winter color of buffalograss and zoysiagrass can be enhanced by colorant application, and a longer period of acceptable color can be achieved by applying at a higher volume or by including a sequential midwinter treatment.

$\mathrm{T}$ he transition zone of turfgrass adaption, a loosely defined area in the central United States which includes Kansas, experiences wide ranges of temperature extremes and makes turfgrass management difficult. Water is a limited resource and its use for landscape irrigation is under increasing scrutiny.

We appreciate the funding provided by the Heart of America Golf Course Superintendents Association, KS Golf Course Superintendents Association, and Kansas Turfgrass Foundation in support of this project. Thanks are extended to Tim Todd, for his assistance with data analysis. Colorant information and assistance provided by Grady Miller, Don Spier, and Jennifer Seevers was greatly appreciated. Contribution no. 17-283-J from the Kansas Agricultural Experiment Station

${ }^{1}$ Department of Horticulture and Natural Resources, Kansas State University, 2021 Throckmorton Plant Science Center, Manhattan, KS 66506

${ }^{2}$ Department of Plant Pathology, Kansas State University, 4024 Throckmorton Plant Science Center, Manhattan, KS 66506

${ }^{3}$ Corresponding author. E-mail: rossbraun@ksu.edu doi: 10.21273/HORTTECH03690-17
Warm-season turfgrasses are more heat and drought resistant than cool-season grasses, and their use results in water savings (Fry and Huang, 2004). In addition, warm-season turfgrass also require fewer pesticide and fertilizer inputs compared with cool-season turfgrasses (Fry and Huang, grasses remain green late into the autumn and also green up earlier in the spring, whereas warm-season grasses 2004). However, cool-season turf- turn brown after the first autumn frost and remain dormant until mid to late spring. Some turf managers in the transition zone may avoid the use of warm-season grasses because customers object to the brown color during dormancy.

The warm-season grasses buffalograss and zoysiagrass are well adapted to the transition zone because of their excellent cold tolerance (Beard, 1973). Among the characteristics of interest to buffalograss and zoysiagrass managers are extended fall color and early spring green-up (Fry and Huang, 2004). During winter dormancy, a dormant brown color gradually occurs after the first autumn frost, and once spring soil temperatures rise above $50{ }^{\circ} \mathrm{F}$, color slowly returns (Beard, 1973). Buffalograss has a light tan to straw-brown color when dormant and an intermediateto-fair spring green-up rate (Beard, 1973). In Kansas, buffalograss generally enters dormancy in early to midOctober and greens up in early May. As a result of its extended winter dormancy in northern climates, acceptance of buffalograss as a turfgrass species has been limited (Riordan, 1991). In Kansas, 'Meyer' zoysiagrass usually takes on a straw-brown color of dormancy in October and begins to green up in mid to late April (Okeyo et al., 2011). The dormancy period for buffalograss and zoysiagrass can be unappealing to turfgrass managers and golfers, especially when cool-season grasses that retain color longer in autumn and green up sooner in spring are grown in the same vicinity.

Measured visual color and quality of dormant buffalograss were improved in Nebraska after treatment with the turf colorant LESCO Green (John Deere Landscapes, Alpharetta, GA) (Shearman et al., 2005), but there is a lack of research with other products. In the southern United

\begin{tabular}{llll}
\hline $\begin{array}{l}\text { Units } \\
\text { To convert U.S. to SI, } \\
\text { multiply by }\end{array}$ & U.S. unit & SI unit & $\begin{array}{l}\text { To convert SI to U.S., } \\
\text { multiply by }\end{array}$ \\
\hline 3.1833 & $\mathrm{fl} \mathrm{oz} / 1000 \mathrm{ft}^{2}$ & $\mathrm{~L} \cdot \mathrm{ha}^{-1}$ & 0.3141 \\
0.3048 & $\mathrm{ft}$ & $\mathrm{m}$ & 3.2808 \\
3.7854 & $\mathrm{gal}$ & $\mathrm{L}$ & 0.2642 \\
9.3540 & gal/acre & $\mathrm{L} \cdot \mathrm{ha}^{-1}$ & 0.1069 \\
2.54 & inch $(\mathrm{es})$ & $\mathrm{cm}$ & 0.3937 \\
4.8824 & $\mathrm{lb} / 1000 \mathrm{ft}^{2}$ & $\mathrm{~g} \cdot \mathrm{m}^{-2}$ & 0.2048 \\
6.8948 & $\mathrm{psi}$ & $\mathrm{kPa}$ & 0.1450 \\
$\left({ }^{\circ} \mathrm{F}-32\right) \div 1.8$ & ${ }^{\circ} \mathrm{F}$ & ${ }^{\circ} \mathrm{C}$ & $\left({ }^{\circ} \mathrm{C} \times 1.8\right)+32$
\end{tabular}


States, turf colorants have been used as an alternative to overseeding with cool-season grasses to improve color and quality of hybrid bermudagrasses (Cynodon dactylon $\times$ C. transvaalensis) and manilagrass (Zoysia matrella) during winter dormancy (Briscoe et al., 2010; Liu et al., 2007).

In Kansas, we found that the colorants Green Lawnger (BASF Corp., Florham Park, NJ) and Match Play Bermudagrass (Pioneer Athletics, Cleveland, $\mathrm{OH}$ ) (referred to as Match Play Ultradwarf Super in Braun, 2014) applied at $262 \mathrm{gal} /$ acre once or twice during dormancy of lawn-height 'Chisholm' zoysiagrass resulted in distinct differences and duration of acceptable color (Braun, 2014). Based on results by other researchers and our work with colorants on 'Chisholm', it is clear that more information is needed on how to most effectively manage colorants on buffalograss and zoysiagrass in the transition zone. Therefore, our objectives were to evaluate the effect of one vs. two colorant applications and application volume on persistence of green color in dormant buffalograss and zoysiagrass.

\section{Materials and methods}

STUdY SITES AND TREATMENTS. The buffalograss colorant experiment was conducted at the Rocky Ford Turfgrass Research Center in Manhattan, KS (Rocky Ford) and the John C. Pair Horticulture Center in Haysville, KS (Pair Center). Soil at Manhattan was a Chase silt loam; at Haysville, soil was a Canadian-Waldeck fine sandy loam. Turf was 'Sharpshooter' buffalograss in Manhattan and 'Cody' buffalograss in Haysville. At both sites, turf was maintained at a 2.5-inch height, which would be common for golf course roughs and home lawns, and received an annual June nitrogen application of $\mathrm{l} \mathrm{lb} / 1000 \mathrm{ft}^{2}$ from urea $(46 \mathrm{~N}-0 \mathrm{P}-0 \mathrm{~K})$, representing a low-input fertility system.

The zoysiagrass colorant experiment was conducted at Rocky Ford and Colbert Hills Golf Course in Manhattan, KS (Colbert Hills). Soil at Rocky Ford was the same as for the buffalograss experiment; at Colbert Hills, soil was a Clime-Sogn complex. Turf at both sites was 'Meyer' zoysiagrass maintained at
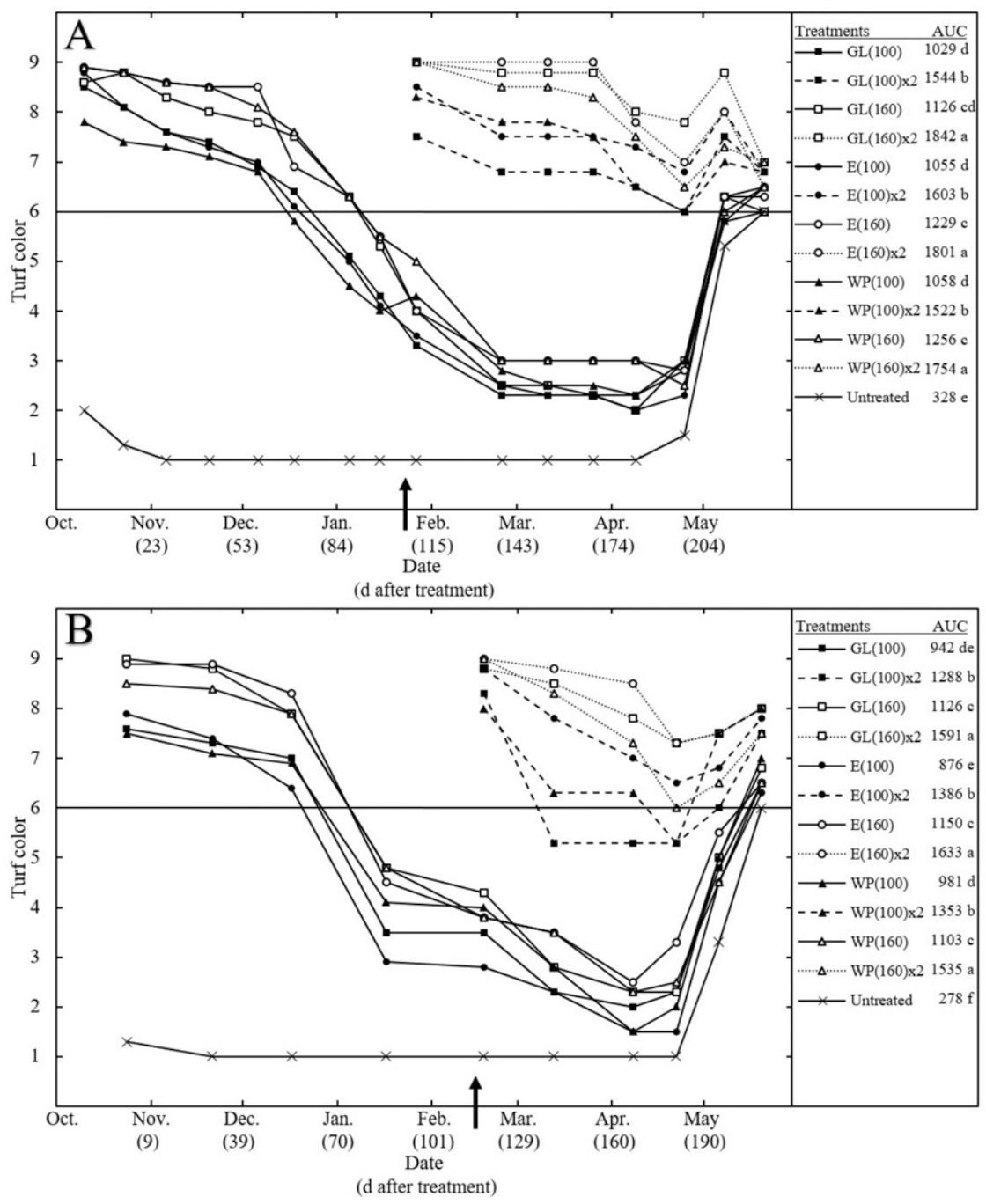

Fig. 1. Effect of colorants and application volumes on turf color of (A) 'Sharpshooter' buffalograss at the Rocky Ford Turfgrass Research Center, Manhattan, KS (Rocky Ford) and (B) 'Cody' buffalograss at the John C. Pair Research Center, Haysville, KS (Pair Center) in 2013-14. Colorants were applied on 10 Oct. 2013 at Rocky Ford and on 24 Oct. 2013 at the Pair Center. The black arrows indicate the dates when a sequential midwinter application was made on 25 Jan. 2014 (108 d after the initial application) at Rocky Ford and on 18 Feb. 2014 (118 d) at the Pair Center; GL = Green Lawnger (BASF Corp., Florham Park, NJ); $\mathrm{E}=$ Endurant (Geoponics Corp, Naples, FL); WP = Wintergreen Plus (Precision Laboratories, Waukegan, IL); $100=100 \mathrm{gal} / \mathrm{acre} ; 160=160 \mathrm{gal} / \mathrm{acre} ; \mathrm{x} 2=$ treatment received a sequential midwinter application $\left(1 \mathrm{gal} / \mathrm{acre}=9.3540 \mathrm{~L} \cdot \mathrm{ha}^{-1}\right)$. Turf color was rated on a 1 to 9 scale where $1=$ straw brown, $6=$ acceptable green color (light green), and 9 = dark green. The solid black horizontal line signifies minimum rating for acceptable turf color. Area under the curve (AUC) incorporated visual turf color data over the entire study, and greater AUC indicates better winter turf color. Means followed by the same letter are not significantly different according Fisher's protected least significant difference test $(P \leq 0.05)$.

a 0.5 -inch height, typical of golf course fairways, and nitrogen at $1-2 \mathrm{lb} / 1000 \mathrm{ft}^{2}$ per year from urea was applied between June and $\mathrm{Au}-$ gust. No mowing occurred on the buffalograss and zoysiagrass sites during the experiments.

The turf plots at Rocky Ford and the Pair Center were on flat terrain under full-sun conditions, receiving only foot traffic from rating plots. Experimental plots at Colbert Hills were on a slight westward facing sloped fairway under full-sun conditions and received foot traffic from rating plots and foot and golf cart traffic from golfers. The location, however, was in an area where foot 

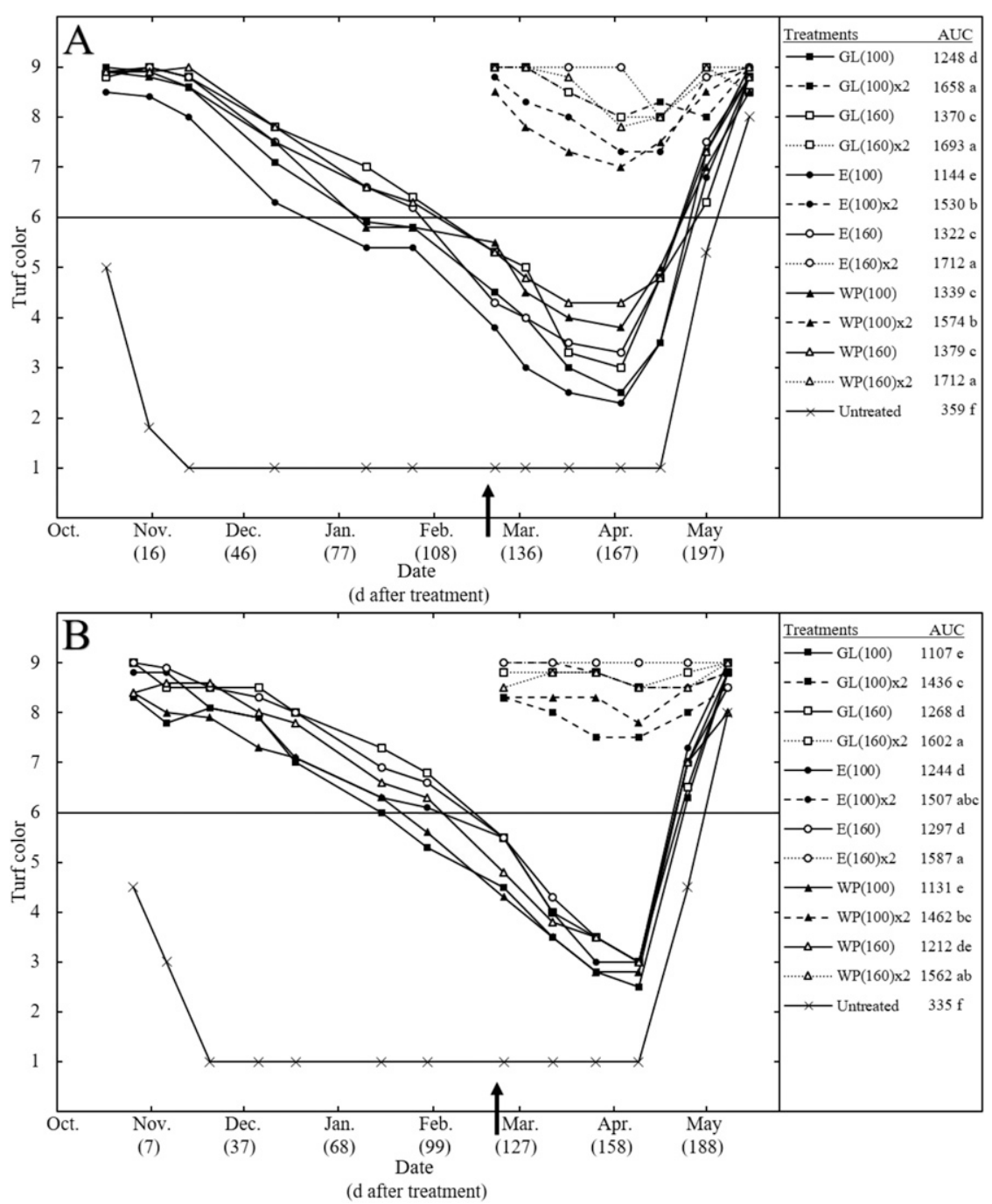

Fig. 2. Effect of colorants and application volumes on turf color of 'Meyer' zoysiagrass at (A) the Rocky Ford Turfgrass Research Center, Manhattan, KS (Rocky Ford) and (B) Colbert Hills Golf Course, Manhattan, KS (Colbert Hills) in 2013-14. Colorants were applied on 17 Oct. 2013 at Rocky Ford and 26 Oct. 2013 at Colbert Hills. The black arrows indicate the dates when a sequential midwinter application was made on $18 \mathrm{Feb} .2014$ (125 d after the initial application) at Rocky Ford and on 24 Feb. 2014 (122 d) at Colbert Hills; GL = Green Lawnger (BASF Corp., Florham Park, NJ); E = Endurant (Geoponics Corp, Naples, FL); WP = Wintergreen Plus (Precision Laboratories, Waukegan, $\mathrm{IL}) ; 100=100 \mathrm{gal} / \mathrm{acre} ; 160=160 \mathrm{gal} / \mathrm{acre} ; \mathrm{x} 2=$ treatment received a sequential midwinter application $\left(1 \mathrm{gal} / \mathrm{acre}=9.3540 \mathrm{~L} \cdot \mathrm{ha}^{-1}\right)$. Turf color was rated on a 1 to 9 scale where 1 = straw brown; $6=$ acceptable green color (light green), and $9=$ dark green. Solid black horizontal line signifies minimum rating for acceptable turf color. Area under the curve (AUC) incorporated visual turf color data over the entire study, and greater AUC indicates better winter turf color. Means followed by the same letter are not significantly different according Fisher's protected least significant difference test $(P \leq 0.05)$.

and cart traffic was minimal. Manhattan, KS, typically has a 2-3-week longer winter dormancy period for the studied warm-season grasses than Haysville, KS. Mean maximum and minimum air temperatures from mid-October to mid-May in Haysville, KS, were 53 and $28.8^{\circ} \mathrm{F}$, respectively, and total precipitation included three turf paint colorants: 1) Green Lawnger; 2) Endurant (Geoponics Corp, Naples, FL); and 3) Wintergreen Plus (Precision Laboratories, Waukegan, IL). Each colorant was applied at either 100 or $160 \mathrm{gal} / \mathrm{acre}$ at two application timings: 1) a single autumn application; 2 ) an autumn application plus a sequential midwinter (e.g., late January to midFebruary) application. An untreated "control" was also included for comparison of dormant turf color.

Colorants were applied using a three-nozzle, carbon dioxide $\left(\mathrm{CO}_{2}\right)$ pressurized sprayer with $8002 \mathrm{VS} \mathrm{noz}^{-}$ zles (TeeJet Technologies, Springfield, IL) calibrated to deliver $0.40 \mathrm{gal} / \mathrm{min}$ at 20 psi and at a dilution of 1:6 (colorant:water) by volume. At each application timing, two passes were made in perpendicular directions on each plot, with one half of the total treatment volume (i.e., 100 or 160 gal/acre) applied in each direction based on sprayer speed. The three colorants and two spray volumes were chosen based on results by other researchers and on our previous work with colorants on 'Chisholm' zoysiagrass (Braun, 2014; Briscoe et al., 2010; Liu et al., 2007). Endurant, a new colorant at the time experiments were initiated, was included for that reason.

'Sharpshooter' buffalograss with $10 \%$ to $15 \%$ green turf color remaining (based on visual evaluation) received its first colorant application on 10 Oct. 2013 at Rocky Ford. 'Cody' buffalograss with $5 \%$ to $10 \%$ green turf color remaining was treated on 24 Oct. 2013 at the Pair Center. Plots receiving the sequential application at Rocky Ford were treated on 25 Jan. 2014 (108 d after the initial application), whereas those at the Pair Center were treated on 18 Feb. 2014 (118 d after the first colorant application).

'Meyer' zoysiagrass with $15 \%$ to $20 \%$ green turf color remaining at both sites was treated with colorants on 17 Oct. 2013 at Rocky Ford and on 26 Oct. 2013 at Colbert Hills. Sequential colorant applications were made on 18 Feb. 2014 at Rocky Ford (125 d after the initial application) and 24 Feb. 2014 at Colbert Hills (122 d after the initial application). For each buffalograss and zoysiagrass site, the sequential midwinter application timing was scheduled to follow 


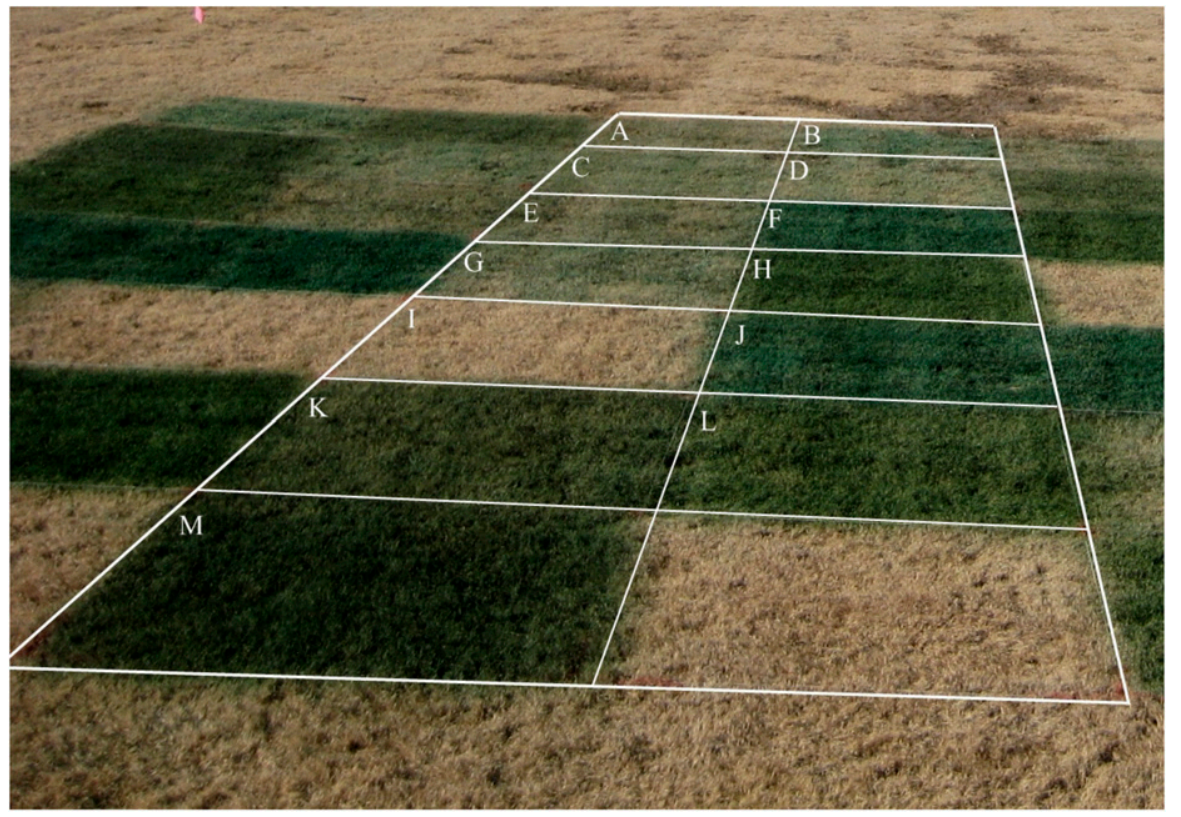

Fig. 3. 'Sharpshooter' buffalograss color on 21 Feb. 2014, $31 \mathrm{~d}$ after a sequential application and $138 \mathrm{~d}$ after the initial application at the Rocky Ford Turfgrass Research Center, Manhattan, KS. (A) Green Lawnger (BASF Corp., Florham Park, NJ) at $100 \mathrm{gal} / \mathrm{acre}$-one application, (B) Wintergreen Plus (Precision Laboratories, Waukegan, IL) at $160 \mathrm{gal} / \mathrm{acre}$-one application, (C) Endurant (Geoponics Corp, Naples, FL) at 160 gal/acre-one application, (D) Endurant at $100 \mathrm{gal} / \mathrm{acre}$ - one application, (E) Green Lawnger at $160 \mathrm{gal} / \mathrm{acre}$-one application, (F) Wintergreen Plus at $160 \mathrm{gal} / \mathrm{acre}$ - two applications,

(G) Wintergreen Plus at $100 \mathrm{gal} / \mathrm{acre}$-one application, (H) Endurant at 160 gal/acre - two applications, (I) Untreated, (J) Wintergreen Plus at $100 \mathrm{gal} / \mathrm{acre}$ two applications, (K) Green Lawnger at $100 \mathrm{gal} / \mathrm{acre}$ - two applications, (L) Endurant at $100 \mathrm{gal} / \mathrm{acre}$ - two applications, and (M) Green Lawnger at 160 gal/acre-two applications $\left(1 \mathrm{gal} /\right.$ acre $\left.=9.3540 \mathrm{~L} \cdot \mathrm{ha}^{-1}\right)$.

the rating date where all colorant treatment means had decreased to below acceptable visual turf color (rating <6).

Data Collection and analysis. Visual turf color was rated on a 1 to 9 scale where $1=$ straw brown; $6=$ acceptable green color for a lawn/ golf course; and $9=$ dark green, with color rating based on the intensity of the color, not the color (hue) of green (Morris and Shearman, 1999). Visual turf color was rated every other week at Colbert Hills and both buffalograss and zoysiagrass sites at Rocky Ford. Visual turf color was rated monthly from 24 Oct. to 8 Apr. and then every other week from 8 Apr. to 20 May at the Pair Center. Area under the curve (AUC) analysis was conducted on visual turf color data to give a cumulative, winter-long indication of turf color. Area under the curve was calculated as $\mathrm{AUC}=\sum^{n i-1}{ }_{i=1} \quad\left\{\left[\mathrm{y}_{i}+\right.\right.$ $\left.\left.\mathrm{y}_{(i+1)}\right] / 2\right\}\left(\mathrm{t}_{(i+1)}-\mathrm{t}_{i}\right)$; where $i$ is the order index for the times, $y_{i}$ is the visual color rating, $t_{i}$ is the time at $i$ th rating, and $n i$ is the number of times (Shaner and Finney, 1977). Spring green-up of turfgrass was measured by visually inspecting new turf growth extending above the turf canopy, along with turf color ratings by investigators during April/May rating dates.

Residual normality was tested with the $w$ statistic of the ShapiroWilk test using the UNIVARIATE procedure of SAS (version 9.4; SAS Institute, Cary, NC) (Shapiro and Wilk, 1965). Data were subjected to a 3-fold nested analysis of variance using the GLIMMIX procedure of SAS (version 9.4). Factors were application timing nested within application volume nested within colorant, application volume nested within colorant, and colorant. Means were separated using Fisher's protected least significant difference test $(P \leq 0.05)$. A homogeneity of variance test for location by treatment effect was significant for corresponding study sites associated with either buffalograss or zoysiagrass; therefore, results will be presented separately for each site.

\section{Results and discussion}

For visual turf color evaluated as AUC, the effect of application timing nested within application volume nested within colorant was significant $[P<0.05$ (Figs. 1 and 2 )]. For visual turf color ratings, there was no significant difference $(P>0.05)$ for the application timing nested within application volume nested within colorant for the single autumn application until the rating dates immediately after the sequential midwinter application (Figs. 1 and 2). Therefore, application volume means (solid lines before black arrow) presented are based on $n=8$ for 100 and 160 gal/acre until sequential midwinter application indicated by the black arrow. Following the sequential midwinter application timing through remainder of the study, means for application timing nested within application volume nested within colorant (solid and dashed lines after black arrow) are based on $n=4$ (Figs. 1 and 2).

Buffalograss. Colorant-treated buffalograss receiving either a single autumn application or an autumn application + sequential midwinter application had superior color compared with untreated buffalograss for 182-224 d at Rocky Ford [10 Oct. to 9 Apr. or 21 May (Fig. 1A)] and 155 to $209 \mathrm{~d}$ at Pair Center [24 Oct. to 13 Mar. or 20 May (Fig. 1B)]. Ranking of AUC color values, regardless of location or colorant, was two applications at $160 \mathrm{gal} / \mathrm{acre}>$ two applications at $100 \mathrm{gal} / \mathrm{acre}>$ one application at $160 \mathrm{gal} / \mathrm{acre} \geq$ one application at $100 \mathrm{gal} / \mathrm{acre}>$ untreated buffalograss (Fig. 1). A greater AUC color value indicates better winter turf color.

When applied once in autumn at $100 \mathrm{gal} /$ acre at Rocky Ford, colorants provided acceptable color (rating 26) for $58-70 \mathrm{~d}$, based on the last observed date that a rating better than acceptable color was observed (Fig. 1A). Likewise, at $160 \mathrm{gal} /$ acre buffalograss color was acceptable for at least $88 \mathrm{~d}$ at Rocky Ford. At the Pair Center, all colorants provided acceptable color for at least $55 \mathrm{~d}$ at 100 and $160 \mathrm{gal} /$ acre (Fig. 1B). Across locations, colorants, and volumes, the period of unacceptable color before 


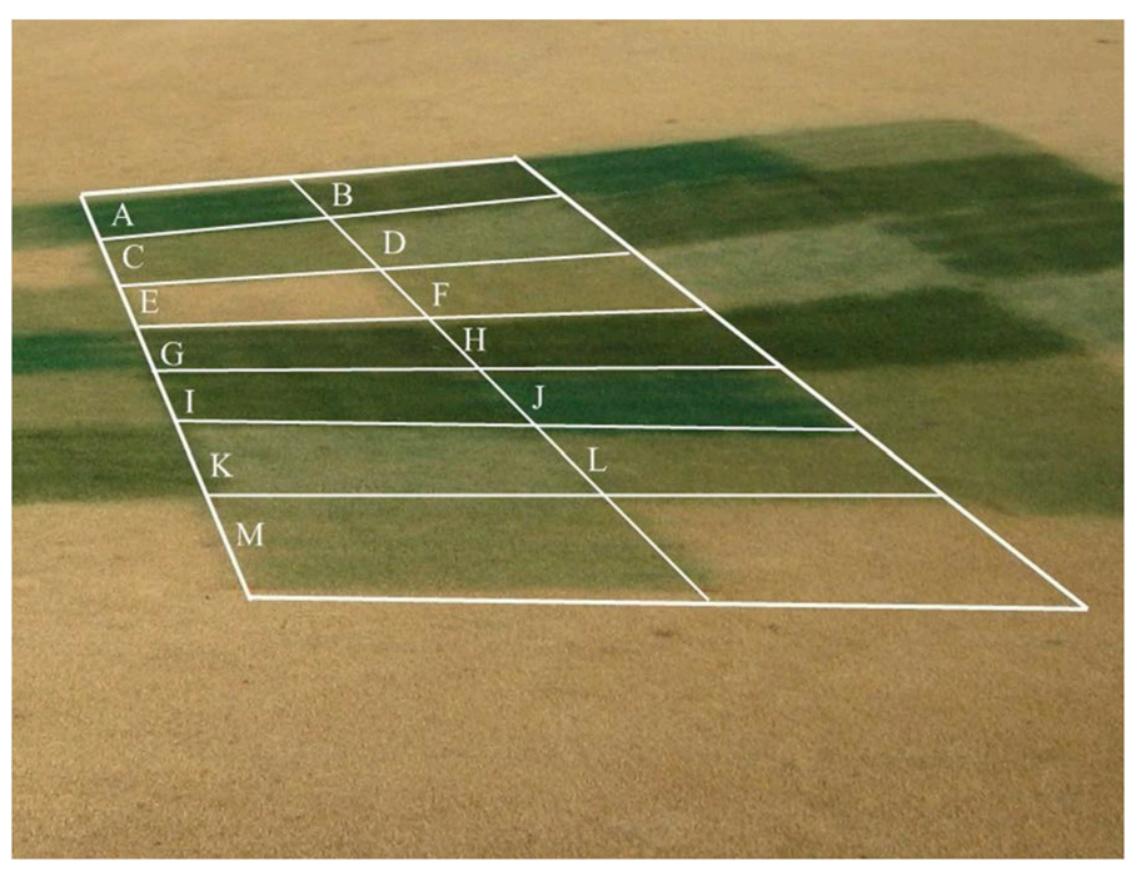

Fig. 4. 'Meyer' zoysiagrass visual color on $24 \mathrm{Feb}$. 2014, $1 \mathrm{~d}$ after a sequential colorant application and $122 \mathrm{~d}$ after the initial application at Colbert Hills Golf Course, Manhattan, KS. (A) Wintergreen Plus (Precision Laboratories, Waukegan, IL) at 100 gal/acre-two applications, (B) Green Lawnger (BASF Corp., Florham Park, NJ) at 100 gal/acre-two applications, (C) Endurant (Geoponics Corp, Naples, FL) at 160 gal/acre-one application, (D) Wintergreen Plus at $100 \mathrm{gal} / \mathrm{acre}$-one application, (E) Untreated, (F) Green Lawnger at 100 gal/acre-one application, (G) Green Lawnger at $160 \mathrm{gal} / \mathrm{acre}$ - two applications, $(\mathrm{H})$ Endurant at $160 \mathrm{gal} / \mathrm{acre}$ - two applications, (I) Endurant at $100 \mathrm{gal} / \mathrm{acre}$ - two applications, (J) Wintergreen Plus at $160 \mathrm{gal} / \mathrm{acre}$ - two applications, (K) Wintergreen Plus at 160 gal/acre-one application, (L) Green Lawnger at $160 \mathrm{gal} / \mathrm{acre}$ - one application, and (M) Endurant at $100 \mathrm{gal} / \mathrm{acre}$ one application $\left(1 \mathrm{gal} / \mathrm{acre}=9.3540 \mathrm{~L} \cdot \mathrm{ha}^{-1}\right)$.

the sequential application was applied lasted between 20 and $63 \mathrm{~d}$. Once buffalograss receiving a single autumn colorant application fell below acceptable color, it remained so until early to mid-May. Buffalograss that received a sequential midwinter colorant application at Rocky Ford on 25 Jan. had acceptable color for the remaining $116 \mathrm{~d}$, through spring green-up (Fig. 1A). Buffalograss at the Pair Center receiving a sequential application on $18 \mathrm{Feb}$. had acceptable color for the remaining $9 \mathrm{l} \mathrm{d}$, through spring green-up, with two exceptions: 1) turf receiving a sequential application of Green Lawnger at $100 \mathrm{gal} /$ acre had less than acceptable color on three rating dates (14l-181 d); and 2) turf treated with Wintergreen Plus at $100 \mathrm{gal} /$ acre had less than acceptable color on one rating date $(181 \mathrm{~d})$ (Fig. 1B).

Our findings are similar to a prior study in Nebraska, in which increased application rates led to an increased
Rocky Ford and Colbert Hills occurred on zoysiagrass receiving sequential applications at $160 \mathrm{gal} / \mathrm{acre}$, regardless of colorant. However, a sequential application of Green Lawnger at $100 \mathrm{gal} /$ acre at Rocky Ford and a sequential application of Endurant at $100 \mathrm{gal} /$ acre at Colbert Hills were not statistically different from the $160 \mathrm{gal} / \mathrm{acre}$ treatment at either location. Ranking of AUC color values for zoysiagrass, regardless of location or colorant, was two applications at $160 \mathrm{gal} / \mathrm{acre} \geq$ two applications at $100 \mathrm{gal} / \mathrm{acre}>$ one application at $160 \mathrm{gal} / \mathrm{acre} \geq$ one application at $100 \mathrm{gal} /$ acre $>$ untreated zoysiagrass (Fig. 2).

There were some slight but statistically significant differences among colorants for AUC at a given application volume. For example, a sequential midwinter application of Green Lawnger applied at $100 \mathrm{gal} / \mathrm{acre}$ had a significantly higher AUC value than the same application timing and volume of both Endurant and Wintergreen Plus at Rocky Ford. In addition, Endurant applied once at $100 \mathrm{gal} / \mathrm{acre}$ had a significantly higher AUC value than both Wintergreen Plus and Green Lawnger at Colbert Hills. Lastly, Wintergreen Plus applied once at $100 \mathrm{gal} / \mathrm{acre}$ had a significantly higher AUC value than both Green Lawnger and Endurant at Rocky Ford. These differences among colorants at a given application volume and timing were observed only in zoysiagrass.

Colorants applied at 100 or 160 gal/acre provided acceptable zoysiagrass color immediately after the autumn application. Zoysiagrass at Rocky Ford receiving one autumn colorant application, regardless of brand, had acceptable color for at least $56 \mathrm{~d}$ at $100 \mathrm{gal} / \mathrm{acre}$ and at least $101 \mathrm{~d}$ at $160 \mathrm{gal} / \mathrm{acre}$, based on last observed date above acceptable color rating (Fig. 2A). At Colbert Hills, zoysiagrass receiving one autumn application had acceptable color for 82$97 \mathrm{~d}$ at $100 \mathrm{gal} / \mathrm{acre}$ and at least $97 \mathrm{~d}$ at $160 \mathrm{gal} / \mathrm{acre}$ (Fig. 2B). A period of unacceptable zoysiagrass color occurred before the sequential colorant applications were applied based on the last observed date that a rating better than acceptable color was observed. At Rocky Ford, the number of days that zoysiagrass had less than acceptable color before the sequential application was $69 \mathrm{~d}$ at $100 \mathrm{gal} / \mathrm{acre}$ and $24 \mathrm{~d}$ at 
160 gal/acre. At Colbert Hills, zoysiagrass had less than acceptable color for $25-40 \mathrm{~d}$ at 100 and $160 \mathrm{gal} / \mathrm{acre}$. Regardless of the application volume, a sequential midwinter application on zoysiagrass provided acceptable turf color through the green-up period at both locations.

In an earlier experiment in Kansas done on lawn-height 'Chisholm' zoysiagrass, the same three colorants used in the current study applied once in autumn at $80 \mathrm{gal} /$ acre resulted in acceptable turf color for 55-69 d (Braun et al., 2016). Colorants applied at 160 gal/acre to 'Chisholm' had acceptable color for 69-118 d, and at $240 \mathrm{gal} / \mathrm{acre}$, color was acceptable for 118-167 d. Greater differences in turf color and the duration of acceptable color occurred when application volume was increased 3 -fold from 80 to $240 \mathrm{gal} /$ acre than when application volume was increased from 160 to $240 \mathrm{gal} /$ acre or 80 to 160 gal/acre (Braun et al., 2016). In our current study, the two application volumes of 100 and $160 \mathrm{gal} /$ acre applied once in autumn often resulted in similar durations of acceptable color for the same or comparable application volumes previously investigated (Braun et al., 2016). Furthermore, when colorants were applied once in autumn, the higher application volume of 160 gal/acre resulted in an equal or longer duration of acceptable color compared with $100 \mathrm{gal} / \mathrm{acre}$ at both zoysiagrass sites and the buffalograss site at Rocky Ford, which is similar to past findings (Braun et al., 2016). This increase in persistence of acceptable color due to a higher application volume was not observed on buffalograss at the Pair Center, possibly because there was a gap in visual turf color rating dates because the study at the Pair Center was being rated monthly.

Past research has shown that colorants have the potential to enhance spring green-up of turfgrass. Spring green-up was enhanced when colorants were applied to turfgrass maintained at $0.13,0.16$, and 0.19 inch (Liu et al., 2007). Buffalograss green-up was also enhanced with colorants (Shearman et al., 2005). However, Braun et al. (2016) reported no differences in spring green-up of colorant-treated vs. untreated 'Chisholm' zoysiagrass at 2.5-inch mowing height. In our current study, through visual inspection at multiple rating dates, green leaves were observed emerging from colorant-treated turf 2 weeks earlier than in untreated turf at the 0.5-inch zoysiagrass sites but not at the 2.5-inch buffalograss sites. The ability of colorants to enhance spring green-up is possibly more likely to be observed at lower mowing heights than at higher mowing heights.

On both buffalograss and zoysiagrass, there were differences in type of green color hue among colorant products. Green Lawnger and Endurant provided a dark green color compared with Wintergreen Plus's blue-green color, but Wintergreen Plus still provided an acceptable color option. Green color (hue) preferences will vary from one turf manager to another, but color ratings reflected the intensity of the color, and we did not consider the color (hue) of green in visual ratings. Hue differences in green color among colorant brands were most pronounced immediately after the autumn and midwinter timings, and a representative example on buffalograss and zoysiagrass are shown in Figs. 3 and 4, respectively.

In summary, we observed only minor differences among colorants regarding their effect on visual green color persistence. The period of time that acceptable buffalograss and zoysiagrass color were observed after a single autumn application was generally longer at 160 than $100 \mathrm{gal} /$ acre. Regardless of colorant brand and application volume, a sequential application applied in midwinter on zoysiagrass provided acceptable green turf color from that point until spring green-up. Likewise, a sequential application applied midwinter on buffalograss provided acceptable turf color until spring green-up, with the exception of a few dates at Pair Center where Green Lawnger, Wintergreen Plus, or both applied at $100 \mathrm{gal} / \mathrm{acre}$ were slightly below an acceptable color rating. However, based on the last observed rating date where turf color was at an acceptable rating, there was a period of 20-69 d, depending on colorant, rate, and turf species, during which color fell below an acceptable level before the sequential application was made. More research is needed to evaluate optimum strategies for application volume and timing to maintain acceptable color through the winter months.

\section{Literature cited}

Beard, J.B. 1973. Turfgrass: Science and culture. Prentice-Hall, Englewood Cliffs, NJ.

Braun, R. 2014. Cultural strategies to improve zoysiagrass acceptability and performance in the transition zone. Kansas State Univ., Manhattan, MS Thesis.

Braun, R., J. Fry, M. Kennelly, D. Bremer, and J. Griffin. 2016. Colorant application volume and color persistence on a 'Chisholm' zoysiagrass lawn. HortTechnology 26:314-319

Briscoe, K., G. Miller, and S. Brinton. 2010. Evaluation of green turf colorants as an alternative to overseeding on putting greens. Appl. Turfgrass Sci. doi: 10.1094/ ATS-2010-0326-02-RS.

Fry, J. and B. Huang. 2004. Applied turfgrass science and physiology. Wiley, Hoboken, NJ.

Liu, H., B.L. McCarty, C.M. Baldwin, W.G. Sarvis, and S.H. Long. 2007. Painting dormant bermudagrass putting greens. Golf Course Mgt. 75(11):86-91.

Morris, K.N. and R.C. Shearman. 1999. NTEP turfgrass evaluation guidelines. Natl. Turfgrass Evaluation Program, Beltsville, $\mathrm{MD}$.

Okeyo, D.O., J.D. Fry, D. Bremer, C.B. Rajashekar, M. Kennelly, A. Chandra, D.A. Genovesi, and M.C. Engelke. 2011. Freezing tolerance and seasonal color of experimental zoysiagrass. Crop Sci. 51:2858-2863.

Riordan, T.P. 1991. Buffalograss. Grounds Maintenance 26(2):12-14.

Shaner, G. and R. Finney. 1977. The effect of nitrogen fertilization on the expression of slow-mildewing resistance in Knox wheat. Phytopathology 67:10511056.

Shapiro, S.S. and M.B. Wilk. 1965. An analysis of variance test for normality (complete samples). Biometrika 52:591611.

Shearman, R.C., L.A. Wit, S. Severmutlu, H. Budak, and R.E. Gaussoin. 2005. Colorant effects on dormant buffalograss turf performance. HortTechnology 15: 244-246. 